\title{
Kritis Cendikiawan Muslim Terhadap Penafsiran Quraish Shihab Tentang Jilbab*
}

\author{
(CRITICAL MUSLIM SCHOLAR AGAINST INTERPRETATION \\ OF QURAISH SHIHAB ABOUT HIJAB)
}

\author{
Nandra Sagitarius \& Tjeptjep Suhandi \\ Fakultas Agama Islam UIKA Bogor \\ Jl. KH. Sholeh Iskandar \\ E-mail: nandra.sagitarius@yahoo.com
}

\begin{abstract}
The Qur'an interpreter Quraish Shihab provide conclusions and different interpretations of the religious establishment in providing legal arguments about the veil. He said that the head is not the nakedness because he thinks that the provisions will limit tolerable from the genitalia or female body is zhanniy not qathi ', in addition to the Qur'anic verse provides no details clearly and forcefully about the limits of the genitalia, such as what is mentioned in the Qur'an Surah An-Nur verse 31 and Surah Al-Ahzab verse 59. from these different thoughts, arise wide criticism from Muslim scholars to the thought of Quraish Shihab.
\end{abstract}

Keywords: Criticism, Interpretation, Hijab

\begin{abstract}
Abstrak: Penafsir Alquran Quraish Shihab memberikan kesimpulan dan penafsiran yang berbeda dari kebanyakan ulama dalam memberikan argumentasi hukum tentang jilbab. Ia mengatakan bahwa kepala bukan aurat karena menurutnya bahwa ketetapan hukum tentang batas yang ditoleransi dari aurat atau badan wanita bersifat zhanniy bukan qathi', selain ayat Alquran tidak memberikan rincian secara jelas dan tegas tentang batas aurat, seperti apa yang disebutkan dalam Alquran Surat An-Nur ayat 31 dan Surat Al-Ahzab ayat 59. Dari pemikiran yang berbeda ini, timbul ragam kritik dari cendekiawan muslim terhadap pemikiran Quraish Shihab.
\end{abstract}

Kata Kunci: Kritik, Penafsiran, Jilbab

* Diterima tanggal naskah diterima: 30 Maret 2013, direvisi: 7 April 2013, disetujui untuk terbit: 12 Mei 2013. 


\section{Pendahuluan}

Sejak awal dikenal manusia, pakaian lebih berfungsi sebagai penutup tubuh daripada sebagai pernyataan lambang status seseorang dalam masyarakat. Sebab berpakaian merupakan perwujudan dari sifat dasar manusia yang mempunyai sifat rasa malu sehingga selalu berusaha menutupi tubuhnya. Oleh karena itu betapapun sederhananya kebudayaan suatu bangsa, usaha untuk menutupi tubuh dengan pakaian itu selalu ada, kendatipun dalam bentuk seadanya seperti halnya orang Irian Jaya pedalaman yang hanya memakai holim (koteka) bagi laki-laki dan sali yokal bagi perempuan, yaitu suatu busana hanya menutupi bagian-bagian tertentu dari tubuhnya. ${ }^{1}$ Kemudian ketika arus zaman telah berkembang pakaian tidak lagi sebatas penutup aurat saja tetapi sebagai mode atau gaya hidup.

Ketika pakaian bukan hanya dijadikan sebagai penutup aurat tetapi juga sebagai mode atau perhiasan, hal ini memang tidak salah. Sebab Allah SWT sendiri menyuruh kita untuk membaguskan pakaian yang kita pakai, sebagaimana firman Allah Surat Al-A'raaf ayat 31. "Hai anak Adam, pakailah pakaianmu yang indah di setiap (memasuki) Masjid. Tetapi walaupun hal itu dianjurkan, mereka tetap memakai aturan-aturan berpakaian yang diatur oleh Alquran dan hadits yaitu harus menutup seluruh badan selain yang dikecualikan, kainnya harus tebal dan tidak tipis, tidak diberi wewangian yang terlalu berlebihan, tidak menyerupai laki-laki dan tidak menyerupai wanita kafir. ${ }^{2}$ Semua aturan tersebut tidak lain adalah untuk meninggikan derajat wanita dan agar mereka dianggap terhormat karena kita ketahui bahwa sebelum kedatangan agama Islam para wanita zaman Jahiliyah dahulu hanya memakai pakaian penutup kepala atau khimar yang tidak sampai kedada yang auratnya terbuka pada bagian dada, sehingga menimbulkan rangsangan terhadap para lelaki yang bermaksud jahat terhadap dirinya dan juga tidak diketahui mana yang budak merdeka dan mana yang belum merdeka. ${ }^{3}$

Perintah ini ditujukan kepada semua perempuan yang beriman tanpa membedakan apakah ia berasal dari negara Arab, Indonesia, Amerika, Inggris ataupun negara lain. Mereka tetap harus melaksanakan perintah ini dalam hal

1 Nina Surtiretna, Anggun Berjilbab, Bandung: Al Bayan, 1996, h. 13.

2 Al Ghifari, Kudung Gaul: Berjilbab Tapi Telanjang, cet. 13, Bandung: Mujahid Pers, 2003, h. 62-63.

3 M. Quraish Shihab, Tafsir al Misbah; Pesan, kesan dan Keserasian al Qur'an, Jakarta: Lentera Hati, 2002, h. 319. 
menjaga pandangan, menjaga kemaluan, menampakkan perhiasan yang biasa tampak yaitu muka dan telapak tangan dan bagaimana tata cara berjilbab atau berkerudung.

Para ulama ketika menafsirkan "bagian yang tampak" pada ayat tersebut banyak terjadi perbedaan pendapat. Hal itu dikemukakan oleh Asy Saukani di dalam kitab Nailul Authar yaitu:

1. Aurat wanita adalah seluruh badan kecuali muka dan telapak tangan. Menurut pendapat Imam Syafi'i, Imam Abu Hanifah dan Imam Malik bahwa aurat wanita seluruh badan kecuali muka, telapak tangan, telapak kaki dan letak gelang kaki (di atas tumit dan di bawah mata kaki).

2. Menurut pendapat Imam Ahmad bin Hambal, Imam Abu Hanifah, Abu Daud dan Sufyan Ats Sauri bahwa aurat wanita adalah seluruh badan kecuali muka.

3. Menurut pendapat pengikut Imam Madzhab Syafi'i dan Imam Ahmad bin Hambal bahwa seluruh badan wanita adalah aurat. ${ }^{4}$

Dari perbedaan para ulama tersebut sesungguhnya tidak mengarah kepada perbedaan yang mencolok seperti bolehnya memperlihatkan rambut, dada, perut maupun paha. Perbedaan mereka hanya terletak pada muka, telapak tangan, telapak kaki dan sebagian tangan sampai pergelangan. Namun, dalam ayat ini pakar Tafsir kontemporer yang juga lulusan Mesir yaitu Quraish Shihab memberikan kesimpulan dan penafsiran yang berbeda dari kebanyakan para ulama yaitu bahwa kepala bukan aurat karena menurutnya bahwa ketetapan hukum tentang batas yang ditoleransi dari aurat atau badan wanita bersifat zhanniy bukan qathi', ${ }^{5}$ karena ayat Alquran tidak memberikan rincian secara jelas dan tegas tentang batas aurat, seperti apa yang disebutkan dalam Alquran Surat An-Nur ayat 31 dan Surat AlAhzab ayat 59 .

Seandainya menurut beliau di dalam Alquran ada ketentuan pasti tentang batas aurat, tentunya para ulama baik masa kini maupun ulama terdahulu tidak terjadi perbedaan atau khilafiyah dalam menginterpretasi

4 Muhammad bin Ali bin Muhammad Asy Syaukani, Nailul Authar min Sayyid al Akhyar Syarhu Muntaha Mungal al Akhbar, Beirut: Dar al Kitab al Ilmiyah, 1995, h. 68.

5 M. Quraish Shihab, Tafsir al Misbah; Pesan, kesan dan Keserasian al Qur'an, Jakarta: Lentera Hati, 2002, h. 333. 
ayat tersebut. Begitu juga dengan hadits Nabi yang walaupun para ulama menemukan hadits Nabi, tetapi masih juga ditemukan perbedaan dalam hal penilaian kualitas suatu hadits. ${ }^{6}$

Kesimpulan yang dikemukakan oleh Quraish Shihab tersebut sebenarnya bisa menimbulkan keraguan oleh kaum mukminat dalam mengamalkan ayat tersebut, yang kalau dibaca sepintas dan tidak merujuk lagi pendapat para ulama terdahulu yang lebih kuat. Parahnya lagi, apabila yang membaca atau mendengar pendapat beliau berasal dari orang awam yang mempunyai latar belakang pendidikan yang rendah akan dapat menimbulkan keraguan atau kebingungan yang sangat berlebihan, yang pada akhirnya auratnya tidak ditutup lagi. Akibat pendapat beliau yang mengatakan bahwa dalil tentang batas aurat bersifat zhanniy dan masih terdapat khilafiyah antara para ulama. Apalagi kalau kita membaca buku Quraish Shihab yang berjudul Jilbab Pakaian Wanita Muslimah: Pandangan Ulama Masa Lalu dan Cendikiawan Kontemporer dan beberapa tulisannya yang membahas tentang jilbab, yang secara panjang lebar dikemukakan pandangan Quraish Shihab yang berkenaan dengan batas aurat dan jilbab.

Pendapat Quraish Shihab tersebut yang dianggap berbeda dengan beberapa ulama lainnya. Akhirnya, banyak menuai kritikan dari beberapa cendikiawan muslim contohnya ketika diadakan bedah buku beliau yang berjudul Jilbab Pakaian Wanita Muslimah: Pandangan Ulama Masa Lalu dan Cendikiawan Kontemporer yang bertempat di Pusat Studi Alquran Ciputat hari Kamis, tanggal 21 September 2006 yang sebelumnya juga pernah di bedah di Wisma Nusantara Mesir hari Selasa, tanggal 28 Maret 2006 yang pada saat diskusi banyak terdapat kritikan yang di lontarkan oleh para cendikiawan muslim seperti, Mukhlis Hanafi, Eli al Maliki, Adian Husaini dan Aep Syaipullah yang semuanya menolak pendapat beliau, ketika beliau menafsirkan Alquran surat An-Nur ayat 31 dan Surat Al-Ahzab ayat 59. Akan tetapi ditengah banyaknya kritikan yang diberikan kepada Quraish Shihab tersebut, beliau masih tetap dengan pendapatnya yaitu bahwa jilbab adalah masalah khilafiyah.

6 Adian Husaini, "Jilbab": M Quraish Shihab, Suara Hidayatullah XXIV, 7 November 2006. h. 92-93. 


\section{Penafsiran Quraish Shihab ${ }^{7}$ Surat An-Nur ayat 31 dan Al-Ahzab ayat 59}

Kata ( زينة ) zinah adalah sesuatu yang menjadikan lainnya indah dan baik atau dengan kata perhiasan. Kata (خمر ) khumur adalah bentuk jamak dari kata (خمار ) khimar yaitu tutup kepala, yang panjang. Sejak dahulu wanita menggunakan tutup kepala itu, hanya saja sebagian mereka tidak menggunakannya untuk menutup tetapi membiarkan melilit punggung mereka. Ayat ini memerintahkan mereka menutupi dada mereka dengan kerudung panjang itu. Al-Biqa'i memperoleh kesan dari penggunaan kata ( ( ضرب dharaba yang biasa diartikan memukul atau meletakkan sesuatu secara cepat dan sungguh-sungguh pada firman-Nya: (وليضربن بخمر هنّ ) wal yadhribna bi khumurihinna bahwa pemakaian kerudung itu hendaknya diletakkan sungguh-sungguh untuk tujuan menutupinya. Bahkan huruf $b a$ pada kata $b i$ khumurihinna dipahami oleh sementara ulama berfungsi sebagai al-Ilshaq yakni kesertaan. Ini untuk lebih menekankan lagi agar kerudung tersebut tidak terpisah dari bagian badan yang harus ditutup. ${ }^{8}$

Kandungan ayat ini berpesan agar dada ditutup dengan kerudung. Apakah ini berarti bahwa kepala (rambut) juga harus ditutup. Jawabnya, "Ya". Demikian pendapat yang logis, apalagi jika disadari bahwa "rambut adalah hiasan wanita". Bahwa ayat ini tidak menyebut secara tegas perlunya rambut ditutup, hal ini agaknya tidak perlu disebut. Bukankah mereka telah memakai kerudung yang tujuannya adalah menutup rambut. Memang ada pendapat yang menyatakan bahwa: إلاّ ما ظهر منها illa ma zhahara minha adalah di samping wajah dan kedua telapak tangan, juga kaki dan rambut. Demikian kata Thahir Ibn 'Asyur.

${ }^{7}$ Nama lengkapnya adalah Muhammad Quraish Shihab. Ia lahir tanggal 16 Februari 1944 di Rapang, Sulawesi Selatan. Ia berasal dari keluarga keturunan Arab terpelajar. Quraish Shihab adalah putra Abdurahman Shihab seorang ulama dan guru besar di bidang tafsir. Kecintaan terhadap bidang studi tafsir karena ayahnya yang sering mengajak anaknya duduk bersama. Pada saat seperti inilah sang ayah menyampaikan nasihat yang kebanyakan ayat alQur'an. Sebagai putra dari seorang guru besar, Quraish Shihab mendapatkan motivasi awal dan benih kecintaan terhadap bidang studi tafsir dari ayahnya yang sering mengajak anakanaknya duduk bersama. Ia harus mengikuti pengajian al-Qur'an yang diadakan oleh ayahnya sendiri. Selain menyuruh membaca al-Qur'an, ayahnya juga menguraikan secara sepintas kisah-kisah dalam al-Qur'an, di sinilah, benih-benih kecintaannya kepada al-Qur'an mulai tumbuh.

8 M. Quraish Shihab, Tafsir al Misbah; Pesan, Kesan dan Keserasian al Qur'an, Jakarta: Lentera Hati, 2002, h. 328. 
Bagaimana dengan yang tidak disebut? Tentu saja wanita-wanita berkewajiban memelihara hiasannya sehingga tidak terlihat kecuali apa yang diistilahkan oleh ayat ini dengan kalimat (إلّ ما ظهر منها ) illa ma zhahara minha.

Penggalan ayat ini diperselisihkan maknanya oleh para ulama, khususnya makna illa. Ada yang berpendapat bahwa kata ( إ ) illa adalah istisna' muttashil yang berarti "Yang dikecualikan merupakan bagian/jenis dari apa yang disebut sebelumnya", dan yang dikecualikan dalam penggalan ayat ini adalah zinah atau hiasan. Ini berarti ayat tersebut berpesan: "Hendaklah janganlah wanita-wanita menampakkan hiasan (anggota tubuh) mereka, kecuali apa yang tampak".

Redaksi ini, jelas tidak lurus, karena apa yang tampak tentu sudah kelihatan. Jadi, apalagi gunanya dilarang? Karena itu, lahir paling tidak tiga pendapat lain guna lurusnya pemahaman redaksi tersebut.

Pertama, memahami illa dalam arti tetapi atau dalam istilah bahasa arab istisna munqathi dalam arti yang dikecualikan bukan bagian/jenis yang disebut sebelumnya. Ini bermakna: "Janganlah mereka menampakkan hiasan mereka sama sekali; tetapi apa yang tampak (secara terpaksa/bukan sengaja seperti ditiup angin dan lain-lain), maka itu dapat dimaafkan.

Kedua, menyisipkan kalimat dalam penggalan ayat itu. Kalimat dimaksud menjadikan penggalan ayat itu mengandung pesan lebih kurang: “Janganlah mereka (wanita-wanita) menampakkan hiasan (badan mereka). Mereka berdosa jika demikian. Tetapi jika tampak tanpa disengaja, maka mereka tidak berdosa".

Penggalan ayat itu jika dipahami dengan kedua pendapat di atas tidak menentukan batas bagi hiasan yang boleh ditampakkan, sehingga berarti seluruh anggota badan tidak boleh tampak kecuali dalam keadaan terpaksa.

Pemahaman ini, mereka kuatkan pula dengan sekian hadits, seperti sabda Nabi kepada Ali bin Abi Thalib yang diriwatkan oleh Abu Daud dan At-Tirmidzi melalui Buraidah: Wahai Ali, jangan ikutkan pandangan pertama dengan pandangan kedua. Yang pertama anda ditolerir dan yang kedua anda berdosa.

Ada riwayat lain yang menjadi dasar pendapat di atas yaitu bahwa seorang pemuda bernama al-Fadhl Ibn Abbas, melaksakan ibadah haji Wada' menunggang unta bersama Nabi Muhammad SAW, dan ketika itu ada 
seorang wanita cantik, yang terus-menerus ditatap oleh Al-Fadhl. Maka Nabi memegang dagu al-Fadhl dan mengalihkan wajahnya agar ia tidak melihat wanita tersebut secara terus-menerus. Demikian diriwayatkan oleh Bukhari dari saudara Al-Fadhl sendiri, yaitu Ibnu Abbas. Bahkan penganut pendapat ini merujuk kepada ayat Alquran, surat al Ahzab ayat 53 yang menyatakan: "Dan apabila kamu meminta sesuatu dari mereka, maka mintalah dari belakang tabir". Ayat ini walaupun berkaitan dengan permintaan sesuatu dari istri Nabi, namun dijadikan oleh ulama penganut kedua pendapat di atas, sebagai dalil pendapat mereka.

Ketiga, memahami firman-Nya "kecuali apa yang tampak" dalam arti yang biasa dan atau dibutuhkan keterbukaannya sehingga harus tampak." Kebutuhan di sini dalam arti menimbulkan kesulitan bila bagian badan tersebut ditutup. Mayoritas ulama memahami penggalan ayat tersebut dalam arti ketiga ini. Cukup banyak hadits yang mendukung pendapat ini. Misalnya: "Tidak dibenarkan bagi seorang wanita yang percaya kepada Allah dan hari kemudian untuk menampakkan kedua tangannya, kecuali sampai di sini Nabi kemudian memegang setengah tangan beliau. (HR. Ath-Thabari).

Di atas telah dikemukakan bahwa zinah adalah sesuatu yang menjadikan sesuatu yang lain indah yakni hiasan. Sementara ulama membaginya dalam dua macam. Ada yang bersifat khilqiyyah (fisik melekat pada diri seseorang) dan juga yang bersifat muktasabah (dapat diupayakan). Menurut Ibn 'Asyur yang bersifat fisik melekat adalah wajah, telapak tangan dan setengah dari kedua lengan, sedang yang diupayakan adalah pakaian yang indah, perhiasan, celak mata dan pacar. Memang Alquran menggunakan kata zinah dalam arti pakaian. Pakar hukum dan tafsir Ibn al-'Arabi berpendapat bahwa hiasan yang bersifat khilqiyyah adalah sebagian besar jasad perempuan, khususnya wajah, kedua pergelangan tangannya, kedua siku sampai dengan bahu, kedua betis dan rambut.

Sedangkan hiasan yang diupayakan adalah hiasan yang merupakan hal-hal yang lumrah dipakai sebagai hiasan buat perempuan yakni perhiasan, pakaian indah dan berwarna warni, pacar, celak, siwak dan sebagainya. Hiasan khilqiyyah yang dapat ditoleransi adalah hiasan yang bila ditutup mengakibatkan kesulitan bagi wanita, seperti wajah, kedua telapak tangan dan kedua kaki, lawannya adalah hiasan yang disembunyikan atau harus ditutup, seperti bagian atas kedua betis, kedua pergelangan, kedua bahu, leher dan bagian atas dada dan kedua telinga. 
Pakar tafsir al-Qurthubi, dalam tafsirnya mengemukakan bahwa ulama besar Said bin Jubair, Atha dan Al-Auzaiy berpendapat bahwa yang boleh dilihat hanya wajah wanita, kedua telapak tangan dan busana yang dipakainya. Sedang sahabat Nabi Ibnu Abbas, Qatadah, dan Miswar bin Makhzamah, berpendapat bahwa yang boleh termasuk juga celak mata, gelang, setengah dari tangan yang dalam kebiasaan wanita Arab dihiasi/diwarnai dengan pacar anting, cincin, dan semacamnya. AlQurthubi juga mengemukakan hadits yang menguraikan kewajiban menutup setengah tangan.

Syaikh Muhammad Ali As-Sais, Guru Besar Universitas Al-Azhar Mesir, mengemukakan dalam tafsirnya yang menjadi buku wajib pada Fakultas Syariah Al-Azhar bahwa Abu Hanifah berpendapat kedua kaki, juga bukan aurat. Abu Hanifah mengajukan alasan bahwa ini lebih menyulitkan dibanding dengan tangan, khususnya bagi wanita-wanita miskin di pedesaan yang (ketika itu) seringkali berjalan (tanpa alas kaki) untuk memenuhi kebutuhan mereka. Pakar hukum Abu Yusuf bahkan berpendapat bahwa kedua tangan wanita bukan aurat, karena dia menilai bahwa mewajibkan untuk menutupnya menyulitkan wanita.

Dalam ajaran Alquran memang ditegaskan bahwa kesulitan merupakan faktor yang menyebabkan munculnya kemudahan. Secara tegas al-Quran surat al Maidah ayat 6, menyatakan bahwa: "Allah tidak ingin menyulitkan kamu". Dan bahwa Allah berfirman dalam surat al Baqarah ayat 185; "Allah menghendaki kemudahan bagimu dan tidak menghendaki kesulitan".

Pakar tafsir Ibnu Athiyah sebagaimana dikutip oleh Al-Qurthubi berpendapat: Berdasarkan redaksi ayat, wanita diperintahkan untuk tidak menampakkan dan berusaha menutup segala sesuatu yang berupa hiasan. Pengecualian, berdasarkan keharusan gerak menyangkut (hal-hal) yang mesti, atau untuk perbaikan sesuatu dan semacamnya. Kalau rumusan Ibnu Athiyah diterima, maka tentunya yang dikecualikan itu dapat berkembang sesuai dengan kebutuhan mendesak yang dialami seseorang.

Hanya al-Qurthubi berkomentar, bagaikan ingin menutup kemungkinan pengembangan dengan menyatakan: Pendapat (Ibnu Athiyah) ini baik. Hanya saja karena wajah dan kedua telapak tangan seringkali (biasa) tampak baik sehari-hari maupun dalam ibadah seperti ketika shalat dan haji, maka sebaiknya redaksi pengecualian "kecuali yang tampak darinya" dipahami sebagai kecuali wajah dan kedua telapak tangan yang biasa tampak itu. 
Demikian terlihat pakar hukum ini mengembalikan pengecualian tersebut kepada yang berlaku. Dari sini, dalam al-Quran dan Terjemahnya yang disusun Tim Departemen Agama, pengecualian itu diterjemahkan sebagai kecuali yang biasa tampak darinya. Apakah "kebiasaan" yang dimaksud berkaitan dengan kebiasaan wanita pada masa turunnya ayat ini, atau kebiasaan wanita di setiap masyarakat Muslim dalam masa yang berbedabeda. Ulama tafsir memahami kebiasaan dimaksud adalah kebiasaan pada masa turunnya al-Quran, seperti yang dikemukakan al-Qurthubi di atas.

Demikian pandangan ulama al Mutaqaddimin (terdahulu) tentang batas-batas yang ditoleransi dalam pakaian wanita, tidak dapat disangkal bahwa pendapat tersebut masih banyak sekali pendukungnya hingga kini, dan memang juga ada hadits-hadits yang menjadi pijakannya. Namun demikian, seperti yang penulis uraikan dalam buku "Wawasan Alquran" bahwa "Amanah ilmiah mengundang penulis untuk mengemukakan pendapat yang berbeda yang boleh jadi dapat dijadikan bahan pertimbangan dalam menghadapi kenyataan yang ditampilkan mayoritas wanita muslim dewasa ini." 9

Muhammad Thahir Ibn 'Asyur seorang ulama besar dari Tunis, yang diakui otoritasnya dalam bidang ilmu agama, menulis dalam bukunya Maqashid asy Syariah bahwa: "Kami percaya bahwa adat kebiasaan satu kaum tidak boleh dalam kedudukannya sebagai adat untuk dipaksakan terhadap kaum lain atas nama agama, bahkan tidak dapat dipaksaan pula terhadap kaum itu."

Ulama ini kemudian memberikan contoh dari Alquran dan sunnah Nabi. Contoh yang diangkatnya dari Alquran adalah surat al-Ahzab ayat 59 yang memerintahkan kaum Mukminah agar mengulurkan jilbabnya.

"Hai Nabi, katakanlah kepada isteri-isterimu, anak-anak perempuanmu dan isteri-isteri orang mukmin: "Hendaklah mereka mengulurkan jilbabnya ke seluruh tubuh mereka". yang demikian itu supaya mereka lebih mudah untuk dikenal, karena itu mereka tidak diganggu. dan Allah adalah Maha Pengampun lagi Maha Penyayang."

Di sini ulama tersebut berkomentar: "Ini adalah ajaran yang mempertimbangkan adat orang-orang Arab, sehingga bangsa-bangsa lain yang tidak menggunakan jilbab, tidak memperoleh bagian, tidak berlaku bagi mereka ketentuan ini." Ketika menafsirkan surat al-Ahzab yang berbicara

\footnotetext{
9 M. Quraish Shihab, Wawasan Al Qur'an, Bandung: Mizan Pustaka, 2003, h. 178.
} 
tentang jilbab ulama ini menulis bahwa: "Cara memakai jilbab berbeda-beda sesuai dengan perbedaan keadaan wanita dan adat mereka. Tetapi tujuan perintah ini adalah seperti bunyi ayat itu yakni "Agar mereka dapat dikenal (sebagai wanita muslim yang baik) sehingga mereka tidak diganggu."

Tetapi bagaimana dengan ayat-ayat ini, yang menggunakan redaksi perintah. Jawabnya, yang sering terdengar dalam diskusi adalah: Bukankah tidak semua perintah yang tercantum dalam Alquran merupakan perintah wajib. Pernyataan itu, memang benar. Perintah menulis hutang piutang salah satu contohnya yaitu dalam Alquran surat al Baqarah ayat 282.

Tetapi bagaimana dengan hadits-hadits yang demikian banyak. Jawabanya pun sama. Thahir Ibn 'Asyur mengemukakan sekian banyak hadits yang menggunakan redaksi perintah, anjuran atau larangan tetapi maksudnya sebaiknya ditinggalkan. Seperti larangan memakai emas dan sutra buat lelaki. Demikian juga perintah tasymit al 'athis (mendoakan yang bersin bila mengucapkan al Hamdulillah), atau perintah mengunjungi orang sakit dan mengantar jenazah, yang kesemuanya hanya merupakan anjuran yang sebaiknya dilakukan bukan seharusnya. Akhirnya, kita boleh berkata bahwa menutup seluruh badan kecuali wajah dan telapak tangan, menjalankan bunyi teks ayat itu, bahkan mungkin berlebih. Namun dalam saat yang sama kita tidak wajar menyatakan terhadap mereka yang tidak memakai kerudung, atau yang menampakkan sebagian tangannya, bahwa mereka "secara pasti telah melanggar petunjuk agama." Bukankah Alquran tidak menyebut batas aurat. Para ulama pun ketika membahasnya berbeda pendapat. Namun demikian, kehati-hatian amat dibutuhkan, karena pakaian lahir dapat menyiksa pemakainya sendiri apabila ia tidak sesuai dengan bentuk badan si pemakainya. Demikian pun pakaian batin. Apabila tidak sesuai dengan jati diri manusia sebagai hamba Allah SWT. Sebagai akhir ayat ini, ada baiknya di garis bawahi dua hal.

Pertama, Alquran dan as-Sunnah secara pasti melarang segala aktifitas fasif atau aktif yang dilakukan seseorang bila diduga dapat menimbulkan rangsangan birahi kepada lawan jenisnya. Apapun bentuk aktifitas itu, sampai-sampai suara gelang kaki pun dilarangnya, bila dapat menimbulkan rangsangan kepada selain suami. Di sini tidak ada tawar menawar.

Kedua, tuntutan Alquran menyangkut berpakaian sebagaimana terlihat dalam ayat di atas, di tutup dengan ajakan bertaubat, demikian juga surat al 
Ahzab ditutup dengan pernyataan bahwa Allah Maha Pengampun lagi maha Penyayang.

Ajakan bertaubat agaknya merupakan isyarat bahwa pelanggaran kecil atau besar terhadap tuntutan memelihara pandangan kepada lawan jenis, tidak mudah dihindari oleh seseorang. Maka setiap orang dituntut untuk berusaha sebaik-baiknya sesuai kemampuannya. Sedangkan kekurangannya, hendaknya dia mohonkan ampun dari Allah, karena Dia Maha Pengampun lagi Maha Penyayang.

Pernyataan bahwa Allah Maha Pengampun lagi maha Penyayang semoga mengandung arti bahwa Allah mengampuni kesalahan mereka yang lalu dalam hal perpakaian. ${ }^{10}$

Kalimat (نساء المؤمنين ) nisa' al mukminin diterjemahkan oleh tim Depertemen Agama dengan istri-istri orang mukmin. Penulis lebih cenderung menerjemahkannya dengan wanita-wanita orang-orang mukmin sehingga ayat ini mencakup juga gadis-gadis semua orang mukmin bahkan keluarga mereka semua.

Kata ( عليهن ) 'alaihinnal di atas mereka mengesankan bahwa seluruh badan mereka tertutupi oleh pakaian. Nabi mengecualikan wajah dan telapak tangan atau beberapa bagian lain dari tubuh wanita, dan penjelasan Nabi itulah yang menjadi penafsiran ayat ini.

Kata ( جلباب ( ) diperselisihkan maknanya oleh ulama. al-Biqa'i menyebutkan beberapa pendapat. Antara lain, baju yang longgar atau kerudung penutup kepala wanita, atau pakaian yang menutup wanita. Semua pendapat ini menurut al-Biqa'i dapat merupakan makna kata tersebut, kalau yang dimaksud dengannya adalah baju, maka ia adalah menutupi tangan dan kakinya, kalau kerudung, maka perintah mengulurkannya adalah menutup wajah dan lehernya, kalau maknanya pakaian yang menutupi baju, maka perintah mengulurkannya adalah membuatnya longgar sehingga menutupi semua badan dan pakaian. ${ }^{11}$

10 M. Quraish Shihab, Tafsir al Misbah; Pesan, Kesan dan Keserasian al Qur'an, Jakarta: Lentera Hati, 2002, h. 334.

11 M. Quraish Shihab, Tafsir al Misbah; Pesan, Kesan dan Keserasian al Qur'an, Jakarta: Lentera Hati, 2002, h. 320. 
Thabathaba'i memahami kata jilbab dalam arti pakaian yang menutupi seluruh badan atau kerudung yang menutupi kepala dan wajah wanita. Thahir Ibn 'Asyur memahami kata jilbab dalam arti pakaian yang lebih kecil dari jubah tetapi lebih besar dari kerudung atau penutup wajah. Ini diletakkan wanita di atas kepala dan terulur kedua sisi kerudung itu melalui pipi hingga keseluruh bahu dan belakangnya. Thahir Ibn 'Asyur menambahkan bahwa model jilbab bisa bermacam-macam sesuai perbedaan keadaan dan selera wanita dan yang diarahkan oleh adat kebiasaan. Tetapi tujuan yang dikehendaki ayat ini adalah "menjadikan mereka lebih mudah dikenal sehingga mereka tidak diganggu."

Ayat di atas tidak memerintahkan wanita muslimah memakai jilbab, karena agaknya ketika itu sebagian mereka telah memakainya, hanya saja cara memakainya belum mendukung apa yang dikehendaki ayat ini. Kesan ini diperoleh dari redaksi ayat di atas yang menyatakan jilbab mereka dan yang diperintahkan adalah "Hendaklah mereka mengulurkannya". Ini berarti mereka telah memakai jilbab tetapi belum mengulurkannya. Terhadap mereka yang telah memakai jilbab, tentu lebih-lebih lagi yang belum memakainya, Allah berfirman: "Hendaklah mereka mengulurkan jilbabnya."

Firman-Nya: (و كان الله غفورا رحيما ) Allah Maha Pengampun lagi Maha Penyayang dipahami oleh Ibn 'Asyur sebagai isyarat tentang pengampunan Allah atas kesalahan mereka yang mengganggu sebelum turunnya petunjuk ini. Sedang al-Biqa'i memahaminya sebagai isyarat tentang pengampunan Allah kepada wanita-wanita mukminah yang pada masa itu belum memakai jilbab sebelum turunnya ayat ini.

Dapat juga dikatakan bahwa kalimat itu sebagai isyarat bahwa mengampuni wanita-wanita masa kini yang terbuka auratnya, apabila mereka segera menutupnya atau memakai jilbab, atau Allah mengampuni mereka yang tidak sepenuhnya melaksanakan tuntunan Allah SWT dan Rasul-Nya, selama mereka sadar akan kesalahan dan berusaha untuk menyesuaikan diri dengan petunjuk-petunjuk-Nya. ${ }^{12}$

\section{Penafsiran Ulama Tentang Jilbab}

1. Muhammad Nasib ar Rifa'i

12 M. Quraish Shihab, Tafsir al Misbah; Pesan, Kesan dan Keserasian al Qur'an, Jakarta: Lentera Hati, 2002, h. 321. 
Ayat jilbab merupakan perintah dari Allah bagi kaum wanita mukmin dan merupakan penghargaan dari Allah bagi suami mereka serta sebagai perbedaan antara mereka dengan wanita jahiliahdn perilaku wanita musyrik. Sebab turunnya ayat ini adalah sebagaimana diceritakan oleh Muqatil bin Hayan. Dia berkata, "Telah sampai berita kepada kami, dan Allah Maha Tahu, bahwa Jabir bin Abdillah al Anshari telah menceritakan bahwa Asma' binti Murtsid tengah berada di tempatnya, yaitu di Bani Haritsah, tiba-tiba banyak wanita menemuinya tanpa menutup aurat dengan rapi sehingga tampaklah gelang-gelang kaki mereka, dada, dan kepang rambutnya. Asma' berguman; 'Alangkah buruknya hal ini.' Maka Allah menurunkan ayat, "Katakanlah kepada wanita beriman, hendaklah mereka menahan padangannya" dari perkara yang diharamkan Allah untuk melihatnya, kecuali kepada suaminya. Karena itu, sebagian ulama berpandangan bahwa wanita tidak boleh melihat laki-laki asing secara mutlak. ${ }^{13}$

Sebagian ulama berpendapat bahwa wanita boleh melihat laki-laki lain jika tidak desertai syahwat. Hal ini ditegaskan dalam kitab shahih Muslim.

"Sesungguhnya Rasulullah melihat sekelompok pria habsyi yang tengah bermain tari perang di dekat masjid pada hari raya. Sementara itu, Aisyah ummil Mukminin ikut melihat mereka dari belakang Nabi. Nabi menghalangin Aisyah dari pandangan mereka dan sesudahnya Aisyah merasa bosan, lalu pulang."

Firman Allah Ta'ala, "Memelihara kemaluan" dari berbagai bentuk pencabulan seperti zina dan perbuatan lain yang ditimbulkan oleh penglihatan. Firman Allah, "Dan janganlah mereka menampakkan perhiasannya kecuali yang biasa nampak darinya." Dikatakan, "Mereka tidak boleh menampakkan perhiasannya sedikit pun kepada pria asing, kecuali perhiasan yang tidak mungkin disembunyikan, seperti selendang yang mempermanis pakaian dan bagian bawah baju." Sehubungan dengan Firman Allah, "Dan janganlah mereka menampakkan perhiasannya kecuali yang biasa nampak darinya," diriwayatkan dari Ibnu Abbas bahwa "yang tampak" itu ialah wajah, kedua telapak tangan dan cincin. Penafsiran sema juga diriwayatkan dari Ibnu Umar, Atha', dan tabi'an lainnya. Malik berkata, "kecuali yang tampak" ialah cincin dan gelang.

13 Muhammad Nasib ar Rifa'i, Ringkasan Tafsir Ibnu Katsir, Jakarta: Gema Insani, cet. I, 2000, h. 488 . 
Boleh jadi Ibnu Abbas dan para pengikutnya itu hendak menafsirkan "apa yang tampak padanya" dengan wajah dan kedua telapak tangan. Dan inilah pendapat yang dikenal oleh mayoritas ulama. Pengecualian tersebut berdasarkan hadits yang diriwayatkan oleh Abu Daud dalam sunannya dari Khalid bin Darik, dari Aisyah r.a. dia berkata Asma' binti Abu Bakar menemui Nabi SAW dengan mengenakan pakaian tipis, lalu Nabi bersabda: "Hai Asma' wanita yang sudah haid tidak layak terlihat darinya kecuali ini." Beliau menunjuk wajah dan kedua telapak tangan."

Namun, Abu Daud dan Hatim ar Razi berkata, "Hadits ini mursal," karena Khalid bin Darik tidak mungkin mendengar dari Aisyah r.a. Firman Allah Ta'ala, "Dan hendaklah mereka menutup kain kerudung ke dadanya," yakni sekitar leher dan dada agar mereka berbeda dar wanita jahiliah yang suka membuka dada, leher, dan kepang rambutnya. Allah menyuruh wanita mukmin menutup aurat dirinya. Hal ini sebagaimana Allah berfirman, "Hai Nabi, katakanlah kepada istri-istrimu, anak-anak perempuanmu, dan wanita-wanita yang beriman, "Hendaklah mereka menutup jilbab ke tubuhnya." Hal itu lebih mudah untuk dikenal sehingga mereka tidak digannggu lagi.

Al khumur merupakan jamak dari khimar yang berarti sesuatu yang digunakan untuk menutupi kepala dan yang suka disebut oleh orang dengan mukena. Bhukari meriwayatkan dari Aisyah, dia berkata; "Semoga Allah mencurahkan rahmat kepada kaum wanita yang berhijrah pada tahap pertama, karena Allah telah menurunkan ayat, "Dan hendaklah mereka menutup kain kerudung ke dadanya," yakni membelitkan sisa kain penutup kepala ke leher dan dada hingga tertutup.

Firman Allah Ta'ala, "Dan janganlah menampakkan perhiasannya kecuali kepada suami mereka, atau ayah mereka, atau ayah suami mereka, atau putra-putra mereka, atau putra-putra saudara laki-laki mereka, atau putra-putra saudara perempuan mereka." Mereka semua merupakan mahram bagi wanita sehingga jika perhiasannya terlihat oleh mereka, maka tidak mengapa, asal sengaja dipertontonkan. Sehubungan dengan ayat ini Ibnu al Mundzir meriwayatkan dari Ikrimah, setelah Ikrimah membaca ayat, dia berkata, "Dalam ayat itu tidak disebutkan paman dan uwak laki-laki, karena keduanya diikutkan dengan anak keduanya. Maka wanita tidak perlu menutup kain kerudung ke dada dan lehernya di dekat paman dan uwak, sedangkan di hadapan suaminya, tidak ada aurat kecuali bila ada orang lain. Firman Allah Ta'ala, "Atau wanita-wanita Islam." Yakni, wanita boleh menampakkan perhiasannya kepada wanita muslim lain, kecuali kepada wanita dzimmi agar wanita ini 
tidak menceritakan ihwal wanita muslim kepada suaminya. Walaupun wanita muslim dilarang memperlihatkan perhiasan atau auratnya kepada wanita non muslim, namun pelarangan memperlihatkan kepada wanita dzimmi lebih keras, karena mereka dapat melakukan apa yang mereka inginkan, dan wanita muslim mengetahui bahwa hal itu haram, maka dia harus menghindarinya.

Firman Allah Ta'ala, "Atau budak-budak yang mereka miliki." Ibnu Jarir berkata, "yaitu budak wanita musyrik. Wanita muslim boleh menampakkan perhiasannya kepada mereka, walaupun mereka itu musyrik, sebab mereka merupakan budaknya." Mayoritas ulama berpendapat bahwa wanita muslim boleh kelihatan perhiasan di hadapan budaknya baik laki-laki maupun perempuan.

Firman Allah Ta'ala, "Atau pelayan-pelayan laki-laki yang tidak mempunyai keinginan" seperti banci yang tidak memiliki hasrat dan keinginan kepada wanita. Ibnu Abbas berkata, "yang dimaksud ialah orang sakit mental yang tidak memiliki syahwat." Firman Allah Ta'ala, "Atau anak-anak yang belum mengerti tentang aurat wanita." Yakni, boleh terbuka aurat kepada anak-anak yang belum memahami soal wanita dan auratnya, yang berkenaan dengan suara, kelembutan ketika berjalan, gerak, dan diamnya wanita. Jika anak itu masih kecil dan belum memahami hal itu, maka dia boleh saja menemui wanita. Jika anak itu sudah memahami dan mengerti soal wanita seperti dapat membedakan mana yang cantik dan yang jelek, maka dia tidak dibolehkan menemui wanita.

Firman Allah Ta'ala, "Dan Janganlah mereka memukulkan kaki mereka.. salah satu kebiasaan wanita jahiliah ialah apabila mereka berjalan sedang kakinya mengenakan gengge, maka dia memukulkan kakinya ke tanah sehingga laki-laki dapat mendengar gemerincingnya. Lalu Allah melarang wanita mukmin melakukan hal seperti itu. Demikian pula apabila wanita memakai perhiasan yang tersembunyi, lalu tubuhnya digerakkan agar perhiasannya tampak, maka ini pun dilarang. Juga dilarang memakai parfum dan mewangian lainnya ketika keluar rumah sebab laki-laki dapat mencium wanginya.

Firman Allah Ta'ala, "Bertobatlah kamu semua kepada Allah wahai orang-orang yang beriman agar kamu beruntung." Yakni, kerjakanlah aturan dan perilaku mulia yang telah diperintahkan Allah kepadamu dan 
tinggalkanlah perbuatan buruk jahiliah, karena keberuntungan sejati terdapat dalam pelaksanaan perkara yang diperintahkan Allah dan Rasul-Nya. ${ }^{14}$

Allah Ta'ala menyuruh Nabi agar menyuruh wanita-wanita mukmin, terutama istri-istri dan anak-anak perempuan beliau agar mengulurkan jilbab ke seluruh tubuh mereka. Sebab cara berpakaian yang demikian membedakan mereka dari wanita jahiliah dan budak-budak perempuan. Jilbab berarti selendang yang lebih lebar daripada kerudung. Demikian menurut Ibnu Mas'ud, Ubaidah dan Qatadah. Kalau sekarang, jilbab itu seperti kain panjang.

Ali bin Abi Thalhah meriwayatkan dari Ibnu Abbas, dia berkata, "Allah menyuruh wanita mukmin, jika mereka hendak keluar rumah untuk suatu kepentingan, agar menutup wajah mereka mulai dari atas kepala dengan jilbab, yang boleh tampak hanyalah kedua matanya. Ibnu Abi Hatim meriwayatkan dari Ummu Salamah, dia berkata, "Setelah ayat di atas turun, maka wanita Anshar keluar rumah dan seolah-olah di kepala mereka terdapat sarang burung gagak, mereka pun mengenakan baju hitam."

Firman Allah Ta'ala, "Yang demikian itu supaya mereka lebih mudah dikenal, karena itu mereka tidak diganggu." Mujahid menafsirkan, "Jika mereka mengenakan jilbab, maka diketahui bahwa mereka merupakan wanita-wanita merdeka sehingga tidak diganggu oleh orang fasik dengan suatu gangguan atau ejekan. "Firman Allah Ta'ala, "Dan Allah adalah Maha Pengampun lagi Maha Penyayang." Maha Pengampun atas perbuatan yang dilakukan pada masa jahiliah, pada saat mereka belum mengenakan jilbab. ${ }^{15}$

2. Abu A'la al Maududi

Pendapat Abu A'la al-Maududi mengenai tentang jilbab didasarkan kepada penafsirannya terhadap surat al-Ahzab ayat 59. Abu A'la al Maududi menafsirkan jalabib, jamak dari jilbab dengan pakaian yang besar, khimar atau rida'. Abu A'la al Maududi berpendapat bahwa ayat ini turun khusus tentang menutup wajah. Dan dari ayat ini juga dapat dipahamai bahwa wanita ketika keluar rumah diharuskan mengenakan pakaian yang tertutup rapat seperti dengan menggunakan khimar atau niqab, yang merupakan penanda bahwa

${ }^{14}$ Muhammad Nasib ar Rifa'i, Ringkasan Tafsir Ibnu Katsir, Jakarta: Gema Insani, cet. I, 2000, h. 493.

15 Muhammad Nasib ar Rifa'i, Ringkasan Tafsir Ibnu Katsir, Jakarta: Gema Insani, cet. I, 2000, h. 901. 
mereka adalah wanita yang mulia dan agar mereka tidak diganggu oleh orang jahat.

Abu A'la al Maududi juga menyebutkan bahwa seluruh ahli tafsir juga berpendapat dengan pendapat yang sama dalam menafsirkan ayat ini. Al Maududi juga menambahkan bahwa jelas bahwa dari masa sahabat yang terpercaya sampai dengan abad ke-8 Hijriyah, seluruh ahli ilmu memahami ayat dengan satu pemahaman yang sama. Dan apabila merujuk kembali kepada hadits-hadits, maka diketahui bahwa setelah ayat ini turun pada masa Nabi, wanita disyari'atkan mengenakan niqab secara umun. Dan mereka dilarang keluar melakukan perjalanan. ${ }^{16}$

Dari beberapa riwayat di atas, inilah Abu A'la al Maududi mendasarkan argumennya tentang wajibnya wanita mengenakan jilbab. Jelas bahwa al Maududi selalu mendasarkan pendapatnya berdasarkan pada ayatayat al-Qur'an, hadits dan pendapat para sahabat Nabi. Dari hal ini pula bahwa pemahaman yang melatar belakangi pendapatnya tentang jilbab ini merupakan manifestasi dari keprihatinan beliau terhadap kondisi masyarakat tempat beliau berada khususnya, dan negara Islam lainnya secara umumnya.

\section{Muhammad Nashiruddin al Albani}

Menutup seluruh tubuh selain yang dikecualikan. Syarat ini terdapat dalam firman Allah surat An-Nur ayat 31 dan juga terdapat dalam firman Allah surat Al Ahzab ayat 59. Pada ayat pertama diterangkan secara tegas adanya kewajiban bagi seorang wanita menutup semua perhiasan, tidak boleh sedikitpun perhiasan tadi ditampakkan di hadapan orang-orang ajnabi yang bukan mahramnya, kecuali bagian yang biasa tampak tanpa mereka sengaja. Dan ketidaksengajaan tadi tidak menjadi dosa bagi mereka bila dengan segera mereka tutup lagi.

Ibnu Katsir di dalam kitab tafsirnya berkata, "Maksudnya, mereka tidak menampakkan sedikitpun perhiasannya kepada orang-orang ajnabi yang bukan mahramnya, kecuali bagian yang tidak mungkin mereka sembunyikan. Ibnu Mas'ud berkata, 'seperti misalnya selendang dan pakaian.' Maksudnya ialah, tutup kepala yang biasa dikenakan oleh wanita Arab dan pakaian bawahan yang memang biasa mereka nampakkan, maka itu tidak mengapa mereka menampakkan, karena tidak mungkin mereka sembunyikan."

16 Abu A'la al Maududi , Hijab, Beirut: Dar al Fikr, h. 300-302 
Pengertian firman Allah: "kecuali yang biasa nampak" adalah pengertian yang langsung bisa ditangkap dari ayat tersebut. Memang para salaf dari kalangan sahabat dan tabi' in berbeda pendapat dalam menafsirkan perkataan "kecuali yang biasa nampak" ini. Ada yang menafsirkan: 'Pakaian-pakainan luar', dan ada pula yang menafsirkan: celak, cincin, gelang, dan wajah', dan Ibnu Jarir di dalam kitab Tafsirnya: 'Wajah dan kedua telapak tangan.' Hal itu termasuk di dalamnya celak, cincin, gelang, dan inai. Nashiruddin al Albani mengatakan, bahwa pendapat tersebut yang benar dikarenakan ada ijma' wajibnya orang shalat menutup auratnya, dan bahwa perempuan harus membuka wajah dan kedua tangannya ketika shalat sedangkan bagian tubuh lainnya harus tertutup. Meskipun ada diriwayatkan' dari Nabi bahwa beliau membolehkan wanita menampakkan sebagian tangannya. Kalau semua itu sudah menjadi ijma', sebagaimana yang sama-sama kita ketahui, maka berarti wanita dibolehkan membuka bagian badannya yang bukan termasuk aurat sebagaiman yang berlaku ima juga pada laki-laki. Karena bagian badan yang bukan aurat tentu tidak diharamkan untuk ditampakkan. Karena sudah samasama kita ketahui bahwa bagian-bagian tersebut termasuk bagian tubuh yang memang dikecualikan oleh Allah di dalam firman-Nya "kecuali yang biasa nampak". Karena bagian-bagian tubuh itu memang biasa ditampakkan."

Ibnu Jarir meriwayatkan hadits itu dari jalur Qatadah, katanya, "Telah sampai kepada saya bahwa Nabi SAW bersabda, 'Tidak halal bagi seorang wanita yang beriman kepada Allah dan hari akhirat menampakkan tangannya, kecuali sampai ini.' Beliau memegang pertengahan hastanya. "Sanad hadits ini munqathi' (terputus). Hadits ini termasuk hadits mungkar dikarenakan kelemahan sanadnya dan karena berlawanan dengan hadits Nabi yang lebih kuat derajatnya, yaitu hadits Aisyah yang diriwayatkan oleh Abu Daud. Hal ini tidak diragukan lagi oleh orang yang mempunyai pengetahuan tentang ilmu hadits.

Menurut al Albani, pengambilan pendapat semacam itu tidaklah kuat, karena pendapat semacam itu tidak berdasarkan pada pengertian yang langsung ditangkap dari dzahirnya ayat itu. Akan tetapi semata-mata diambil dari kesimpulan fiqih. Jadi, bukan suatu hal yang pasti, karena orang lain bisa membantah dengan berkata, 'Bolehnya wanita membuka wajahnya ketika shalat itu adalah hal yang khusus dalam shalat saja. Tidak boleh hal itu diqiaskan untuk membukanya ketika di luar shalat, karena kedua kondisi tersebut jelas berbeda. 
Sebenarnya al Albani berpendapat boleh bagi seorang wanita membuka wajah dan telapak tangan, baik di dalam maupun di luar shalat. Al Albani berpendapat demikian itu karena ada satu dalil, bahkan beberapa dalil yang mendasarinya. Akan tetapi kesamaan al Albani dengan pembantah adalah dari segi keakuratan dalam menerapkan dalil, bukan dari kebenaran pendapatnya. Karena al Albani makna ayat "kecuali yang biasa nampak" tersebut yang benar adalah sebagaimana yang telah disebutkan di awal pembahasan. Dan pendapat itu dikuatkan oleh penafsiran Ibnu Katsir dan AlQurthubi.

Ibnu Athiyah berkata, 'Dari lafadz ayat di atas, jelaslah bahwa seorang wanita diperintahkan untuk tidak menampakkan apa pun yang merupakan perhiasan baginya dan agar bersungguh-sungguh menyembunyikannya. Adapun pengecualian pada ayat tersebut memang sudah semestinya diberikan kepada wanita untuk melakukan kegiatan atau keperluan lainnya. Jadi, 'yang biasa nampak' pada ayat di atas adalah suatu tuntutan bagi seorang wanita dan yang dimaafkan untuk ditampakkan olehnya.

Al-Qurthubi berkata, 'bahwa pendapat ini baik. Akan tetapi karena pada umumnya terbukanya wajah dan kedua telapak tangan ini adalah didasarkan pada kebiasaan dan ibadah misalnya dalam shalat dan haji, maka selayaknya 'pengecualian' ini dikembalikan kepada dua hal itu saja. Dalil yang menguatkan hal ini adalah hadits yang diriwayatkan oleh Abu Daud, dari Aisyah, bahwa Asma' binti Abu Bakar pernah menemui Rasulullah dengan memakai yang tipis. Rasulullah pun berpaling darinya, dan berkata, "Wahai Asma, sesungguhnya wanita itu bila telah mencapai masa haid tidak patut ada bagian tubuhnya yang kelihatan, kecuali ini dan ini. Beliau berkata begitu sambil menunjuk ke wajah dan kedua telapak tangannya. Ini adalah cara yang paling baik dalam menjaga dan mencegah kerusakan manusia. Maka, janganlah para wanita menampakkan bagian tubuhnya, kecuali wajah dan kedua telapak tangannya. Allah lah yang memberi taufiq dan tidak ada Tuhan selain-Nya."

Komentar al Albani, ulasan dia pun juga perlu dicermati, karena meskipun terbukanya wajah dan telapak tangan itu didasarkan pada kebiasaan, akan tetapi hal itu dilakukan oleh para wanita dengan sengaja. Padahal ayat tersebut menurut pemahaman al Albani adalah mengecualikan apa-apa yang biasa nampak tanpa sengaja. Maka, bagaimana mungkin ayat tersebut dijadikan sebagi dalil yang mencakup bagian tubuh yang nampak dengan sengaja. 
Namun al Albani pun terus memikirkan masalah ini. Akhirnya, pendapat para ulama salaflah yang benar karena ketajaman pikiran mereka. Penjelasannya seperti ini. Sesungguhnya para ulama salaf bersepakat bahwa ayat "kecuali yang biasa nampak" itu adalah ditujukan kepada para wanita mukallaf (sudah terkena beban syariat). Akan tetapi mereka berselisih pendapat, manakah bagian yang tubuh wanita yang boleh secara sengaja ditampakkan itu. Ibnu Mas'ud berpendapat "pakaiannya, yaitu jilbabnya". Ibnu Abbas dab beberapa sahabat yang sependapat dengannya berpendapat, "Wajah dan kedua telapak tangannya'. Jadi, pengertian ayat tersebut ialah: "kecuali yang biasa nampak" sesuai dengan izin dan aturan dari pembuat syariat, yaitu Allah. Bukankah kita sepakat bahwa bila seorang wanita meninggikan jilbabnya sehingga di bagian bawah terlihat pakaian dan perhiasannya, sebagaimana dilakukan wanita-wanita Arab, menurut kesepakatan ulama berarti dia telah melangggar ayat tersebut. Perbuatan wanita ini sama dengan perbuatan wanita dalam pembahasan, yaitu samasama ada unsur kesengajaan, tidak bisa tidak mesti begitu kesimpulannya. Sehingga kalau begitu, titik masalah pada ayat tersebut adalah bukan karena unsur ketidaksengajaan wanita tersebut karena ini merupakan hal yang tidak berdosa bagi pelakunya tanpa ada ulama yang mempermasalahkannya, akan tetapi karena tidak adanya izin dari pembuat syariat, yaitu Allah. Bila syariat telah membolehkan wanita menampakkan sebagian dari perhiasaanya, apakah itu kedua telapak tangan, wajah atau yang lainnya, maka kebolehan ini tidak bisa ditolak dengan alasan kesengajaan sebagaimana yang disebutkan di atas. Karena perbuatan tersebut memang diizinkan, misalnya menampakkan jilbab secara keseluruhan, sebagaimana telah disebutkan tadi. Begitulah hasil penafsiran dari para sahabat yang mengatakan, "Yang dikecualikan dalam ayat tersebut adalah muka dan telapak tangan" dan praktek kebanyakan para wanita pada masa Nabi SAW dan generasi sesudahnya, sebagaima disebutkan dalam riwayat-riwayat mutawatir. ${ }^{17}$ Dari penafsiran para ulama tersebut, dapat ditarik kesimpulan bahwa mereka sepakat atas wajibnya jilbab bagi kaum muslimah.

\section{Kritik Cendikiawan Muslim Terhadap Quraish Shihab}

Penafsiran Quraish Shihab dalam surat An-Nur ayat 31 dan Al-Ahzab Ayat 59, dan buku Quraish Shihab yang membahas tentang jilbab, banyak

17 Muhammad Nashiruddin al Albani, Jilbab Wanita Muslimah, Jogjakarta: Media Hidayah, 2002, h. 50-60. 
menuai kritikan oleh para cendikiawan muslim, karena beliau menyatakan bahwa jilbab adalah masalah khilafiah dan bukan merupakan kewajiban. Cendikiawan dalam bahasa Arab disebut Adib, yaitu seseorang yang mengetahui sedikit dari banyak hal, semua itu didapat dari pengalaman dan bacaan yang dilakukan secara tidak sistematis dan teratur. ${ }^{18}$

Buku Quraish Shihab yang berjudul "Jilbab Pakaian Wanita Muslimah: Pandangan Ulama Masa Lalu Dan Cendikiawan Kontemporer" dan beberapa buku beliau yang membahas tentang jilbab yang menjadi buku yang kontroversi dan banyak menuai kritikan oleh para cendikiawan muslim Indonesia. ${ }^{19}$ Buku beliau tersebut telah 2 (dua) kali dibedah, yaitu:

Pertama, pada hari kamis 21 September 2006, bertempat di Pusat Studi Alquran Ciputat. Lembaga yang dipimpin oleh Quraish Shihab sendiri. Hadir sebagai pembicara pada waktu itu adalah Quraish Shihab, Eli Maliki, Jalaluddin Rakhmat dan Adian Husaini. Dan yang bertindak sebagai Moderator adalah Mukhlis Hanafi.

Kedua, di Mesir, pada hari Selasa, 28 Maret 2006 yang diadakan oleh Forum Studi Alquran (FORDIAN) dan Senat Mahasiswa Fakultas Syari'ah Islamiyah Kairo (SEMAFSI) yang bertempat di Aula Wisma Nusantara. Acara itu dimoderatori oleh Romli Syarqowi, (Mahasiswa Program Magister, Jurusan Tafsir, Universitas al-Azhar). Adapun para pembedahnya yaitu Mukhlis Hanafi (Doktor Tafsir dan Ilmu Al Qur'an, lulusan al Azhar, dan Ahmad Zain An Najah (Mahasiswa Program Doktoral bidang Fiqh, Universitas al Azhar).

Dari kedua acara bedah buku Quraish Shihab tersebut, 4 (empat) orang yang penulis muat dalam skripsi ini, yaitu: Eli Maliki, Mukhlis Hanafi, Adian Husaini, dan Ahmad Zain An Najah.

\section{Eli Maliki}

Berkenaan dengan pendapat Quraish Shihab yang mengatakan bahwa ayat di dalam Alquran, yaitu surat An-Nur ayat 31 dan surat Al-Ahzab ayat 59 .

${ }^{18}$ Ahmad Zain An Najah, Jilbab Menurut Syariat Islam (Meluruskan Pandangan Quraish Shihab), Jakarta: Cakrawala Publishing, 2010, h. 197.

19 M. Quraish Shihab, Jilbab Pakaian Wanita Muslimah; Pandangan Ulama Masa Lalu dan Cedikiawan Kontemporer, Jakarta: Lentera Hati, h. 276. 
Eli Maliki menjelaskan bahwa di dalam kedua ayat tersebut sebenarnya sudah secara tegas menyebutkan batas aurat wanita yaitu seluruh tubuh kecuali muka dan telapak tangan. Menurutnya lagi bahwa para ulama tidak berbeda pendapat tentang masalah ini, yang berbeda hanyalah pada masalah apakah wajah dan telapak tangan yang wajib ditutup. Sebagian mengatakan wajib menutup wajah dan sebagian lagi menyatakan wajah boleh dibuka.

Adapun ulama yang menganggap wajah dan telapak tangan bukan aurat yaitu; Syekh Muhammad Nashiruddin al-Albani dalam kitabnya Hijabul Mar'atil Muslimah fil Kitab wa Sunnah dan mayoritas ulama al Azhar, serta beberapa ulama empat mazhab sepakat bahwa wajah dan kedua telapak tangan bukan aurat bila sekiranya tidak menimbulkan fitnah. Sedangkan ulama yang menganggap wajah wajib ditutup atau dalam hal ini kewajiban bercadar bagi wanita adalah ulama Arab Saudi yaitu Syekh Abdul Aziz bin Baz dan juga Abû A'la Maududi dalam kitabnya al Hijab.

Eli Maliki juga menyatakan sikap Quraish Shihab yang sama sekali tidak mentarjih salah satu pendapat dari para ulama yang telah dikemukakannya dan menyerahkan sepenuhnya kepada masyarakat luas untuk memilih pendapat yang bermacam-macam itu. Padahal menurutnya lebih lanjut bahwa tugas ulama adalah membimbing masyarakat, dengan menunjukkan mana pendapat yang lebih kuat dibandingkan dengan yang lain. Beliau juga mengkritik pendapat Quraish Shihab yang menyatakan, bahwa Perintah mengenakan jilbab adalah bukan berarti sebuah kewajiban. Karena setiap perintah itu bisa juga berupa anjuran seperti dalam Alquran surat al Baqarah ayat 282.

Begitu juga di dalam hadits Nabi tentang perintah mendoakan orang yang bersin apabila ia mengucapkan al Alhamdulillah atau perintah merupakan anjuran yang sebaiknya dilakukan bukan seharusnya". ${ }^{20}$ Padahal menurutnya ayat tentang perintah mengenakan jilbab itu sudah tegas dan jelas menyuruh para muslimah untuk memakai jilbab.

\section{Mukhlis Hanafi}

Mukhlis Hanafi yang merupakan doktor tafsir yang ke-lima dan juga merupakan murid dari Quraish Shihab, dalam hal ini menyampaikan

20 M. Quraish Shihab, Tafsir al Misbah; Pesan, Kesan dan Keserasian al Qur'an, Jakarta: Lentera Hati, 2002, h. 333. 
pendapat yang berbeda dengan gurunya. Contohnya pada pendapat Qurash Shihab yang yang menyatakan bahwa tidak ada keharusan bagi wanita memakai jilbab dan dalil-dalil baik dari Alquran dan hadis yang berkenaan dengan hijab dan jilbab bersifat zhan bukan qathi dan juga para ulama juga masih berbeda pendapat tentang masalah tersebut. Dia secara tegas tidak sependapat dengan gurunya dengan menyatakan bahwa praktik shahabiyat (para sahabat wanita) yang memakai jilbab tidak disanggah oleh Nabi, bahkan dikuatkan.

Pemahaman para shahabiyin, serta penerimaan ummat dari generasi ke generasi, secara keseluruhan menjadi bukti dan qarinah (benang merah) bahwa apa yang dimaksud dengan ayat hijab dan jilbab adalah para wanita harus menutup seluruh tubuh tanpa kecuali, atau dengan pengecualian wajah dan telapak tangan ditambah kelonggaran sedikit; setengah tangan dan kedua kaki tidak lebih dari itu. Lebih lanjut lagi menurutnya tidak ada ulama yang diakui otoritasnya baik dalam masalah fiqh maupun tafsir berpendapat bahwa rambut, leher, betis dan lainnya boleh dibuka.

Mukhlis Hanafi menyatakan bahwa pendapat yang diambil dari gurunya tersebut tidak memiliki otoritas dalam bidang tersebut. Seharusnya pendapat yang seharusnya diambil gurunya tersebut adalah pendapat dari ulama yang keilmuan tidak diragukan lagi seperti Imam empat madzhab maupun Imam Nawawi yang telah diakui keilmuannya oleh dunia Islam.

Adapun pendapat ulama atau cendikiawan kontemporer yang menjadi rujukan Quraish Shihab adalah Muhammad Syahrur, Nawal as Sa'dawi dan Muhammad Sa'id al Asymawi. Diantara cendikiawan kontemporer tersebut yang sering dikutip oleh Quraish Shihab adalah Muhammad Sa'id al Asymawi. Dalam hal ini Quraish Shihab menyatakan pendapat yang sama dengan al Asymawi yaitu bahwa perintah memakai jilbab bukan suatu kewajiban. Karena menurutnya ayat-ayat yang berkaitan dengan masalah kewajiban jilbab sangat terkait dengan konteks tertentu (asbab an Nuzulnya) dan konteks ini hendaknya menjadi pertimbangan utama sebuah keputusan hukum.

Untuk membantah pendapat Asymawi tersebut Mukhlis Hanafi mempunyai dua hal yang perlu diperhatikan yaitu:

Pertama, rangkaian sebelum dan sesudah ayat tentang jilbab dalam surat an-Nur ayat 31 dan al-Ahzab ayat 59, menunjukkan bahwa alasan diwajibkannya memakai jilbab adalah demi al-Hisymah (menjaga kehormatan 
wanita agar tetap terpuji), bukan sekedar untuk membedakan mana wanita merdeka dan mana yang hamba sahaya.

Kedua, istilah asbab an Nuzul (sebab-sebab turunnya ayat Alquran), dalam tradisi Ulama Islam tidak dimaksudkan untuk menggambarkan hubungan sebab-akibat, yang berarti kalau peristiwa itu tidak turun, maka ayatnya tidak turun. Tapi lebih berperan sebagai peristiwa yang mengiringi turunnya ayat. Selain itu, mengkhususkan lafazh ayat Alquran hanya berlaku pada kasus tertentu, tidak bersifat umum, berarti menzalimi lafazh itu sendiri.

3. Adian Husaini

Dalam diskusi tersebut Adian Husaini menjadi pembicara dalam membedah buku Qurash Shihab yang bertempat di Pusat Kajian studi Alquran, Ciputat. Menanggapi pendapat Quraish Shihab tersebut Adian Husaini juga menolak pendapat dari Quraish Shihab yang mengatakan bahwa masalah jilbab adalah masalah khilafiyah. Padahal menurut Adian Husaini perbedaan pendapat mereka itu tidak terlepas dari apakah muka dan telapak tangan, telapak kaki dan sebagian tangan sampai pergelangan tangan jika ada hajat yang mendesak.

Menurutnya lagi bahwa kesimpulan yang dikemukakan oleh Quraish Shihab yang menyatakan bahwa jilbab adalah masalah khilafiyah, seyogyanya perlu diklarifikasi lagi karena perbedaan mereka tidak lebih dari apakah muka dan telapak tangan wajib ditutup, dan ulama sepakat bahwa bagian yang boleh nampak hanyalah muka dan telapak tangan.

Adapun yang menurut Quraish Shihab bahwa konsep "aurat wanita" dalam Islam bersifat "kondisional", "lokal", dan "temporal". Adian Husaini mengatakan bahwa kesimpulan itu cukup riskan karena bisa menimbulkan penafsiran baru terhadap hukum-hukum Islam lainnya sesuai dengan asas lokalitas, seperti yang banyak dilakukan sejumlah orang dalam menghalalkan perkawinan antara Muslimah dengan laki-laki non Muslim, hanya berlaku untuk kondisi Arab waktu itu, karena rumah tangga Arab didominasi oleh laki-laki. Sedangkan sekarang, karena wanita sudah setara dengan laki-laki di rumah tangga sesuai dengan perinsip gender equlity maka hukum itu sudah tidak relevan lagi. Dari pendapat ulama yang otoratif dapat disimpulkan bahwa ayat-ayat Alquran yang berbicara tentang aurat wanita dan pakaian wanita bersifat universal berlaku untuk semua Mukminat. 
Menanggapi berbagai kritikan cendikiawan muslim tersebut, Quraish Shihab berusaha bersikap tenang dengan menyatakan bahwa apa yang dikemukakannya berkenaan dengan ketidakharusan wanita muslimah mengenakan jilbab adalah karena beliau hanya mengemukakan berbagai macam pendapat pakar tentang jilbab tanpa menentukan suatu pilihan atau belum bisa mentarjih berbagai macam pendapat. ${ }^{21}$

\section{Ahmad Zain An Najah}

Dalam masalah jilbab, Quraish Shihab cenderung untuk mendukung pendapat yang mengatakan bahwa batasan pakaian dalam Islam disesuaikan dengan kondisi dan adat istiadat masyarakat setempat. Jika pakaian tersebut layak dan pantas serta wajar menurut masyarakat tertentu, maka itulah pakaian yang diperintahkan oleh Islam untuk dipakainya. Banyak pernyataan Quraish Shihab yang menunjukkan hal tersebut, diantaranya: Quraish Shihab menulis: “Terlebih dahulu perlu digaris bawahi bahwa al Qur'an dan sabda, pengamalan dan pembenaran Nabi Muhammad (As-Sunah) kesemuanya turun dan terjadi dalam satu masyarakat yang memiliki budaya." 22

Dalam ilmu Ushul Fiqh, yaitu sebuah disiplin ilmu yang mempelajari tata cara pengambilan hukum dari Alquran dan Hadits disebutkan bahwa pengambilan suatu hukum hanyalah tertumpu pada teks-teks yang ada dalam Alquran dan Hadits yang tentunya menggunakan bahasa Arab, maka salah satu syarat mutlak untuk menjadi mujtahid (yang mampu mengistinbatkan suatu hukum) adalah penguasaan bahasa Arab. Teks-teks yang ada dalam al Qur'an dan Hadits itulah yang akan diolah oleh seorang mujtahid sehingga diperoleh suatu hukum. Tidak disebutkan di dalamnya keharusan memahami budaya masyarakat pada waktu itu sebagaimana yang dianjurkan oleh Quraish Shihab.

Menggulirkan wacana keterkaitan wahyu dengan budaya masyarakat setempat tanpa memberikan keterangan yang lebih jelas dan batasanbatasannya akan berakibat fatal bagi perkembangan hukum Islam, khususnya wacana ini ditangkap oleh sebagian orang yang berfaham liberal dan berusaha melakukan perubahan-perubahan dalam syari'ah Islam tanpa dibekali dengan alat-alat yang memadai. Seluruh ajaran Islam yang sudah

${ }_{21}$ M. Quraish shihab, Jilbab Pakaian Wanita Muslimah: Pandangan Ulama Masa Lalu dan Cendikiawan Kontemporer, Jakarta: Lentera Hati, h. 4-6.

22 M. Quraish Shihab, Jilbab Pakaian Wanita Muslimah: Pandangan Ulama Masa Lalu dan Cendikiawan Kontemporer, Jakarta: Lentera Hati, h. 109. 
baku akan hancur dengan dalih bahwa zaman sudah berubah, dan budaya masyarakat sekarang berbeda dengan masyarakat pada waktu diturunkan al Qur'an.

Maka, konsekwensinya menurut pandangan ini, shalat, ibadah haji, zakat jihad dan lain-lain akan tidak berlaku pada zaman sekarang, karena zaman dan budaya masyarakat sudah berubah, demikian juga bahwa kewajiban wanita muslimah untuk memakai jilbab pun tidak berlaku lagi, karena itu adalah budaya masyarakat setempat dan tidak sesuai dengan perkembangan zaman.

Quraish Shihab menulis: "Persoalan yang muncul lebih jauh adalah, apakah seorang wanita muslimah yang menampakkan selain wajah dan tangannya dapat dinilai telah melanggar tuntunan Allah itu. ${ }^{23}$

Dalam pernyataan di atas, Quraish Shihab mengatakan bahwa wanitawanita yang tidak memakai jilbab belum dapat dinilai bahwa mereka telah melanggar tuntutan Allah. Alasan yang diungkap oleh Quraish Shihab sangat tidak ilmiah, yaitu dengan mengatakan bahwa jika sahabat hidup pada zaman sekarang boleh jadi pemahamannya berbeda. Maksudnya mereka para sahabat jika hidup pada zaman sekarang, mungkin akan berpendapat juga bahwa jilbab itu tidak wajib. Kalau logika berfikir seperti ini diterapkan pada semua hukum Islam, tentunya akan kacau dan hukum-hukum yang telah ditentukan oleh para fuqaha selama berabad-abad lamanya akan rontok dengan sendiri ketika dihadapkan dengan logika yang dipakai oleh Quraish Shihab tersebut. Selain itu, logika tersebut akan memberikan kesempatan bagi orang-orang yang tidak senang dengan Islam untuk menghancurkan Islam dari dalam.

Maka, diharapkan kepada Quraish Shihab untuk lebih berhati-hati di dalam mengungkap argumen, khususnya ketika berbicara tentang suatu hukum dari hukum-hukum Islam. ${ }^{24}$

\section{Hasil Penelitian dan Pembahasan}

${ }_{23}$ M. Quraish Shihab, Jilbab Pakaian Wanita Muslimah: Pandangan Ulama Masa Lalu dan Cendikiawan Kontemporer, Jakarta: Lentera Hati, 2006, h. 111.

${ }^{24}$ Ahmad Zain An Najah, Jilbab Menurut Syariat Islam (Meluruskan Pandangan Quraish Shihab), Jakarta: Cakrawala Publishing, 2010, h. 79-87. 
Ada dua sumber hukum yang dipakai para ulama dalam menentukan batas aurat wanita serta inplikasinya dengan hukum memakai jilbab, Alquran dan hadis-hadits Nabi. Kedua sumber hukum tersebut ditafsirkan oleh para ulama masa lalu sebagai perintah untuk menutup aurat bagi wanita muslimah, akan tetapi ulama kontemporer memiliki penafsiran yang berbeda dari para pendahulunya. Ayat pertama ini dipakai oleh para ulama sebagai dasar dalam menetapkan batas aurat wanita, yaitu firman Allah dalam surat An-Nur ayat 31.

Perbedaan pendapat muncul di kalangan ulama dalam memaknai kalimat illâ mâ zhahara minhâ (kecuali yang biasa nampak dari padanya) dalam ayat ini. Al-Qurthubi mengemukakan bahwa Ibnu Mas'ud memahami makna illâ mâ zhahara minhâ sebagai pakaian. Sedangkan Sa'id bin Jubair, Atha' dan al-Auza'i berpendapat bahwa yang boleh dilihat adalah wajah, kedua telapak tangan di samping busana yang dipakainya. Sementara Ibnu Abbas, Qatadah dan Miswar bin Makhzamah berpendapat bahwa yang boleh dilihat termasuk juga celak mata, gelang, setengah dari tangan yang dalam kebiasaan wanita Arab dihiasi dengan pacar, anting, cincin dan semacamnya. Menurut keterangan Ibnu Umar, Ikrimah dan Atha' dalam riwayat Ibnu Katsir, perhiasan zhahir ialah muka dan kedua telapak tangan, serta cincin. Riwayat Ibnu Katsir yang lain menyatakan bahwa yang dimaksud dengan perhiasan zhahir ialah muka dan telapak tangan. ${ }^{25}$

Ibnu Jarir al-Thabari menjelaskan makna kalimat illâ mâ zhahara minhâ tersebut sebagai muka dan tangan, dan mencakup pula celak mata, cincin, gelang dan cat kuku. Menurut al-Thabari, tafsiran yang paling benar adalah pendapat ijma' bahwa wajib bagi pria yang menjalankan shalat untuk menutup semua bagian tubuh yang disebut aurat, demikian pula bagi perempuan yang menjalankan shalat, kecuali muka dan telapak tangannya. Jika telah ada kesepakatan pendapat tentang itu, maka tak perlu diragukan lagi, bahwa kaum perempuan tetap diperbolehkan membuka bagian tubuhnya yang tidak termasuk aurat, karena tidak diharamkan. Itulah yang dimaksud dengan kalimat illâ mâ zhahara minha. ${ }^{26}$ Selanjutnya pakar yang lain, Ibnu Asyur berpendapat bahwa yang dimaksud hiasan adalah hiasan yang bersifat khilqiyah (melekat) seperti wajah, pergelangan tangan, kedua siku

25 Abu al-Fida' al-Wafa Ismail Ibn Katisr, Tafsir Ibn Katsir, Beirut: Dar al-Fikr, jilid 3, 1986, h. 335.

26 Abu Ja'far Muhammad Ibn Ibn Jarir, Al-Thabari Jami' al-Bayan fi Tafsir al- Qur'an, Beirut: Dar al-Ma'rifah, 1972, h. 84. 
sampai bahu, payudara, kedua betis dan rambut. Sedangkan maksud kalimat illâ mâ zhahara minhâ mengacu pada hiasan khilqiyah yang dapat ditoleransi karena dapat menimbulkan kesulitan apabila ditutup seperti wajah, kedua tangan dan kedua kaki. Banyak ulama memahami kebiasaan yang dimaksud adalah kebiasaan pada masa turunnya Alquran.

Menanggapi perbedaan pandangan para mufassir sebelumnya, Quraish Shihab berpendapat bahwa masing-masing penganut pendapat tersebut sebatas menggunakan logika dan kecenderungannya serta dipengaruhi secara sadar atau tidak dengan perkembangan dan kondisi sosial masyarakat. Batas aurat wanita tidak secara jelas ditegaskan dalam ayat tersebut, sehingga tidak seharusnya menjadi dasar yang digunakan untuk menetapkan batas aurat wanita. ${ }^{27}$

Selain itu, Quraish Shihab juga menegaskan bahwa perintah dan larangan Allah dan Rasul-Nya tidak selalu harus diartikan wajib atau haram, tetapi bisa juga perintah itu bermakna anjuran, sedangkan larangan-Nya dapat berarti sebaiknya ditinggalkan. ${ }^{28}$ Sementara dalam memahami kalimat illâ mâ zhahara minhâ, Quraish Shihab berpendapat bahwa sangat penting untuk menjadikan adat kebiasaan sebagai pertimbangan dalam penetapan hukum, namun dengan catatan adat tersebut tidak lepas kendali dari prinsipprinsip ajaran agama serta norma-norma umum. Karena itu sampai kepada pendapat bahwa pakaian adat yang biasa dipakai oleh putri-putri Indonesia yang tidak mengenakan jilbab tidak dapat dikatakan sebagai telah melanggar aturan agama. ${ }^{29}$

Ayat kedua yang menjadi bahasan pokok tentang pakaian wanita, yaitu firman Allah dalam surat Al-Ahzab ayat 59. Ketika membaca ayat ini juga muncul masalah tentang makna jilbab, karena di sini para mufasir berbeda pendapat. Ibnu Jarir meriwayatkan bahwa Muhammadi Ibn Sirin bertanya kepada Abidah al-Salamani tentang maksud penggalan ayat itu, lalu Abidah mengangkat semacam selendang yang dipakainya dan memakainya sambil menutup kepalanya hingga menutupi pula kedua alisnya dan wajahnya dan membuka mata kirinya untuk melihat dari arah sebelah

27 M. Quraish Shihab, Jilbab Pakaian Wanita Muslimah: Pandangan Ulama Masa Lalu dan Cendikiawan Kontemporer, Jakarta: Lentera Hati, 2006, h. 67.

${ }_{28}$ M. Quraish Shihab, Jilbab Pakaian Wanita Muslimah: Pandangan Ulama Masa Lalu dan Cendikiawan Kontemporer, Jakarta: Lentera Hati, 2006, h. 141-142.

29 M. Quraish Shihab, Tafsir al Misbah; Pesan, Kesan dan Keserasian al Qur'an, Jakarta: Lentera Hati, 2002, h. 333. 
kirinya. Pakar tafsir Al-Alusi menyatakan bahwa yang dimaksud dengan kata 'alaihinna adalah seluruh tubuh mereka, akan tetapi menurutnya ada juga yang menyatakan bahwa yang dimaksud adalah di atas kepala mereka atau wajah mereka karena yang nampak pada masa jahiliyah adalah wajah mereka. ${ }^{30}$

Al-Biqa'i menjelaskan beberapa pendapat seputar makna jilbab. Diantaranya adalah baju yang longgar atau kerudung penutup kepala wanita, atau pakaian yang menutupi baju dan kerudung yang dipakainya, atau semua pakaian yang menutupi badan wanita. Semua pendapat ini menurut ulama itu dapat merupakan makna kata tersebut. Kalau yang dimaksud dengan jilbab adalah baju, maka ia adalah pakaian yang menutupi tangan dan kakinya. Kalau kerudung maka perintah mengulurkannya adalah menutup wajah dan lehernya. Kalau maknanya pakaian yang menutupi baju, maka perintah mengulurkannya adalah membuatnya longgar sehingga menutupi semua badan dan pakaian. Hampir semua ulama sepakat bahwa perintah ayat di atas berlaku bukan saja pada zaman Nabi saw, tetapi juga sepanjang masa hingga kini dan masa yang akan datang. Namun sementara ulama kontemporer memahaminya hanya berlaku pada zaman Nabi di mana ketika itu ada perbudakan dan diperlukan adanya pembeda antara mereka dan wanita-wanita merdeka, serta bertujuan menghindarkan gangguan lelaki usil. Menurut penganut paham terakhir ini, jika tujuan tersebut telah dapat dicapai dengan satu dan cara lain, maka ketika itu pakaian yang dikenakan telah sejalan dengan tuntunan agama. Terlepas apapun makna jilbab yang diyakini oleh tiap-tiap mufasir, yang lebih penting menurut Quraish Shihab adalah apakah perintah mengulurkan jilbab pada ayat tersebut berlaku hanya pada zaman Nabi atau berlaku sepanjang masa.

Quraish Shihab memahami perintah tersebut hanya berlaku pada zaman Nabi, dimana ketika itu ada perbudakan dan diperlukan adanya pembeda antara mereka dan wanita-wanita merdeka, serta bertujuan menghindarkan gangguan lelaki usil. Menurutnya, sebelum turunnya ayat ini, cara berpakaian wanita merdeka atau budak yang baik-baik atau yang kurang sopan hampir dapat dikatakan sama. Karena itu lelaki usil sering kali mengganggu, untuk menghindarkan gangguan tersebut, serta menampakkan kehormatan wanita muslimah ayat di atas turun. ${ }^{31}$

${ }^{30}$ Mahmud Al-Alusi, Ruh al-Ma'ani, Kairo: Al-Muniriyah, 1985, cet. 4, h. 85.

31 M. Quraish Shihab, Jilbab Pakaian Wanita Muslimah: Pandangan Ulama Masa Lalu dan Cendikiawan Kontemporer, Jakarta: Lentera Hati, 2006, h. 309. 
Adapun sumber hukum dari hadits tentang batas aurat wanita yang diperdebatkan para ulama diantaranya adalah hadis berikut:

Pertama, hadits dari Aisyah r.a., ia berkata:

“Bahwa Asma' putri Abu Bakar r.a. datang menemui Rasulullah saw dengan mengenakan pakaian tipis (transparan), maka Rasulullah saw berpaling enggan melihatnya dan bersabda, "Hai Asma', sesungguhnya perempuan jika telah haid maka tidak lagi wajar terlihat darinya kecuali ini dan ini" (sambil beliau menunjuk ke arah wajah dan kedua telapak tangan beliau) (Abu Dawud, kitab al-Libas, hadits no. 4104).

Hadits ini dinilai dengan penilaian yang berbeda-beda oleh para pakar hadits. misalnya Abu Dawud menilai hadits ini mursal karena Khalid bin Duraik yang dalam sanadnya menyebut nama istri Nabi Aisyah r.a. secara pribadi, sedang ia tidak semasa dengan Aisyah. Imam Muslim menyatakan hadits ini mursal, sehingga tidak dapat dijadikan hujjah. Selain Khalid bin Duraik, terdapat nama perawi lain yang juga dianggap bermasalah menurut pandangan pakar hadis, yaitu Said bin Basyir ada yang menilainya dha'if. Sedangkan dari sisi matan, hadits ini juga ditolak karena tidak mungkin Asma' yang terkenal sebagai wanita yang baik dan bertaqwa berani berpakaian tipis ketika menghadap Rasulullah. ${ }^{32}$ Sedangkan al-Albani menilai hadis ini shahîh dengan alasan bahwa ada sekian banyak riwayat yang senada dengannya, sehingga hadis di atas dapat dinilai shahîh. ${ }^{33}$ Hampir sama dengan pendapat al-Albani, Muhammad al-Ghazali yang juga menilai hadits ini mursal menegaskan bahwa karena dikuatkan oleh beberapa riwayat lainnya, hadits ini jauh lebih kuat dibanding hadits yang dijadikan dasar kewajiban menutup seluruh tubuh wanita. Selain itu ia juga berpendapat bahwa ada sebagian wanita pada masa jahiliyah dan juga pada masa Islam yang kadangkadang menutupi wajah mereka seraya membiarkan mata mereka tanpa penutup. Perbuatan seperti ini menurutnya jelas termasuk adat dan sama sekali tidak termasuk ibadah. Karena menurutnya tidak ada ibadah tanpa nash yang jelas. ${ }^{34}$

Kedua, hadits dari Abdullah bia Abbas r.a., ia berkata:

32 Muhammad Ahmad Ismail, Audat al-Hijab, Riyadh: Dar ath-Thibah, jilid 3, h. 339.

${ }_{33}$ Muhammad Nashiruddin al Albani, Jilbab Wanita Muslimah, Jogjakarta: Media Hidayah, 2002, h. 44.

${ }_{34}$ Muhammad Al-Ghazali, As-Sunnah An-Nabawiyah: Baina Ahl Al-Figh wa Ahl AlHadits, Kairo: Dar Asy-syuruq, 1989, h. 55. 
"Rasulullah saw membonceng al-Fadhl putra al-Abbas r.a. pada hari an-Nahr (lebaran Haji) di belakang kendaraan (unta) beliau. Al-Fadhl adalah seorang pria yang berseri (gagah). Nabi saw berdiri memberi fatwa pada khalayak. Lalu datang seorang perempuan dari suku Khats'am, berseri (cantik) dan bertanya kepada Rasulullah saw. al-Fadhl terus-menerus memandangnya dan kecantikan wanita itu menakjubkannya, maka Nabi menoleh sedang al-Fadhl melihat kepada wanita itu, lalu Nabi memalingkan dengan tangan beliau dagu al-Fadhl, beliau memalingkan wajah al-Fadhl dari pandangan kepada wanita itu. lalu wanita itu berkata, "Sesungguhnya kewajiban yang ditetapkan Allah atas hamba-hamba- Nya adalah haji, tetapi saya mendapatkan ayah saya dalam keadaan tua tidak mampu duduk di atas kendaraan, maka apakah boleh saya menghajikan untuknya?" Nabi menjawab, "Ya." (Bukhari, kitab al-Maghazi, hadits no.4048).

Para ulama tidak mempermasalahkan ke-shahih-an hadits ini, meskipun terjadi perdebatan tentang makna hadits tersebut. Hadits ini menunjukkan bahwa terdapat bagian tubuh wanita yang dapat dilihat atau tidak harus ditutup, dalam hal ini menurut banyak ulama adalah wajah dan tangannya. Ulama yang menyatakan seluruh tubuh wanita aurat menolak pemahaman seperti itu. Mereka berargumen dengan alasan, diantaranya: Pertama, perbuatan Nabi memalingkan wajah al-Fadhl menunjukkan adanya larangan menampakkan wajah perempuan. Kalau hal itu dibolehkan, tentu Nabi tidak akan berbuat demikian. Kedua, bisa jadi kecantikan wanita dalam hadits tersebut diketahui melalui bentuk tubuhnya, atau jari-jarinya. Ketiga, kalaupun dikatakan bahwa wajah wanita itu terbuka, maka itu disebabkan karena dia dalam keadaan berihram. Sedangkan wanita yang berihram boleh membuka wajahnya. Sementara ulama yang mengecualikan wajah dan telapak tangan bukan aurat menolak argumen tersebut dengan alasan bahwa perbuatan Nabi membalikkan wajah al-Fadhl bukan karena wajah wanita aurat, tetapi karena Nabi khawatir akan hadirnya setan yang menjerumuskan keduanya apabila pandangan dilanjutkan, apalagi keduanya adalah pemuda dan pemudi. Selain itu, wanita dinilai cantik dengan tanpa melihat wajahnya dan hanya melihat bentuk tubuhnya adalah hal yang mustahil, lagi pula peristiwa itu terjadi di Mina (yakni di hari dan tempat penyembelihan kurban) yang berarti wanita itu telah ber-tahallul dan melepas pakaian ihramnya. Dalam mengomentari hadits ini Quraish Shihab berpendapat bahwa wanita dalam hadits itu terlihat cantik, tanpa menyatakan bahwa wajah dan telapak tangannya terbuka. Memang kecantikan sangat mudah hanya dapat diketahui dari wajah, sehingga kemungkinan terbukanya wajah 
wanita itu merupakan sesuatu yang sangat logis. Bahkan jika ada yang berkata bahwa selain wajahnya misalnya setengah tangannya atau lebih dari itu terlihat pula maka tidak dapat ditolak dengan hadis di atas. ${ }^{35}$

Artinya bisa saja dikatakan bahwa kecantikan wanita itu terlihat jelas sedang ketika itu ia tidak menggunakan jilbab, dan pernyataan semacam ini tidak dapat disalahkan dengan hadis ini. Selain hadis-hadis tersebut, masih ada hadits-hadits lain yang selalu diikuti oleh perdebatan para ulama tentang interpretasinya.

Namun yang dapat disimpulkan dari uraian di atas adalah bahwa para ulama masa lalu dan sebagian ulama kontemporer berbeda pendapat tentang apakah wajah dan telapak tangan aurat atau bukan, tetapi mereka sepakat bahwa rambut wanita adalah bagian dari aurat yang harus ditutup, kecuali bagi mahramnya. Selain kedua pendapat di atas, masih ada lagi beberapa pendapat lain menyangkut aurat wanita meskipun pendapat ini tidak popular, yaitu wajah, kedua telapak tangan dan kedua telapak kaki tidak termasuk aurat, ini adalah pendapat Ats-Tsauri dan Al-Muzani, ulama Hanafiyah serta Syi'ah Imamiyah menurut riwayat yang shahîh. Adapun Quraish Shihab cenderung menganggap bahwa semua kemungkinan yang dikemukakan oleh kedua kelompok ulama tersebut dapat saja terjadi, meskipun sebagian dalil yang dikemukakan terkesan seperti dibuat-buat. Menurutnya, jilbab baik dengan membuka wajah atau menutupnya pada masa Nabi, disamping dipercaya sebagai tuntunan agama juga telah merupakan tuntunan budaya. ${ }^{36}$

Sekali lagi Quraish Shihab menegaskan bahwa interpretasi dalil atau dalih yang dikemukakan oleh para ulama tidak sampai pada batas yang dapat membuktikan secara pasti pendapat masing-masing. Dengan kata lain, Quraish Shihab tidak menganggap bahwa ayat Alquran maupun hadits di atas tidak bisa dijadikan dasar pendapat bahwa selain wajah dan kedua telapak tangan, seluruh bagian tubuh wanita adalah aurat. Di sini Quraish Shihab tampaknya mulai melepaskan diri dari pendapat-pendapat ulama terdahulu yang selama ini menghegemoni pandangan kaum muslimin tentang batas aurat.

${ }_{35}$ M. Quraish Shihab, Jilbab Pakaian Wanita Muslimah: Pandangan Ulama Masa Lalu dan Cendikiawan Kontemporer, Jakarta: Lentera Hati, 2006, h. 107

36 M. Quraish Shihab, Jilbab Pakaian Wanita Muslimah: Pandangan Ulama Masa Lalu dan Cendikiawan Kontemporer, Jakarta: Lentera Hati, 2006, h. 118. 
Selama meneliti pemikiran Quraish Shihab tentang masalah jilbab ini, penulis mencatat ada beberapa poin yang menjadi bahan kritikan peneliti terhadap pendapat Quraish Shihab.

Pertama, Quraish Shihab menyatakan bahwa masalah batas aurat wanita merupakan salah satu masalah khilafiyah. Pendapat itu memang benar, akan tetapi para ulama masa lalu tidak berselisih tentang wajibnya jilbab. Sebagaimana yang telah dijelaskan Quraish Shihab sendiri bahwa para ulama berbeda pendapat dalam menentukan batas aurat wanita. Mereka terbagi menjadi dua kelompok: Pertama, kelompok yang menyatakan seluruh tubuh wanita aurat; Kedua, kelompok yang menyatakan seluruh tubuh wanita aurat, kecuali wajah dan telapak tangan. Artinya para ulama sepakat bahwa memakai jilbab adalah wajib, mereka hanya berbeda pendapat dalam masalah apakah wajah dan telapak tangan termasuk aurat atau tidak. Kecuali kalau Quraish Shihab memasukkan ulama kontemporer tentu dapat dibenarkan bahwa jilbab adalah masalah khilafiyah. Namun jika yang dimaksud adalah ulama masa lalu, maka tentu kurang tepat.

Kedua, pemaparan Quraish Shihab tampak tidak seimbang. Sebab Quraish Shihab lebih banyak menyebutkan pendapat para ulama yang mewajibkan jilbab secara singkat tanpa menjelaskan argumen-argumen mereka secara memadai, sebaliknya Quraish Shihab hanya menyebut beberapa saja dari para ulama dan cendikiawan yang tidak mewajibkan jilbab, meskipun dengan mengemukakan argumen-argumen mereka yang sangat panjang. Hal seperti ini menurut penulis jika dilihat dari sudut pandang ilmiah dapat menurunkan objektifitas Quraish Shihab sebagai pemikir yang benar-benar ingin menyampaikan kebenaran.

\section{Penutup}

Quraish Shihab tidak mewajibkan wanita muslimah memakai jilbab. Menurutnya, memakai jilbab bukanlah termasuk perintah agama, karena tidak boleh dikatakan syari'at tanpa nash yang jelas. Sedangkan pendekatan yang digunakan Quraish Shihab adalah pendekatan tarjih dan pendekatan 'illat al-hukm, serta metode istihsan bi al-'ur. Menurut Quraish Shihab juga ayatayat tentang batasan aurat dan jilbab, yaitu di dalam Alquran surat An-Nur ayat 31 dan surat Al-Ahzab ayat 59, tidak memiliki ketegasan hukum atau dalil tersebut tidak qath'i karena apabila sesuatu masih bersifat zhanniy maka dalil tersebut tidak dapat dijadikan ketetapan hukum. Hal tersebut dapat 
dilihat menurutnya banyak perbedaan ulama baik dalam pengertian jilbab itu sendiri, maupun dari batasan-batasan mana yang boleh ditampakkan kepada yang bukan mahram, dan Pandangan Quraish Shihab juga dipengaruhi oleh pemikiran para cendikiawan kontemporer seperti Muhammad Said Asymawi, Muhammad Syahrur, dan Nawal as Sa'dawi yang tidak memiliki otoritas dalam bidang fiqih. Dan Quraish Shihab secara tidak langsung sependapat dengan para Cendikiawan kontemporer tersebut.

Adapun kritikan cendikiawan muslim terhadap penafsiran Quraish Shihab adalah pernyataan Quraish Shihab yang mengatakan bahwa masalah batas aurat wanita dan jilbab adalah masalah khilafiyah. Walaupun para ulama berbeda pendapat tentang bagian mana yang harus nampak, tetapi perbedaannya tidak jauh berkisar antara apakah wajah dan telapak tangan saja yang boleh dilihat atau seluruh tubuh wanita adalah aurat. Dan para ulama sepakat tentang wajibnya rambut wanita ditutup baik di dalam maupun diluar sholat. Kemudian dalam menafsirkan ayat tentang jilbab ini, Quraish Shihab tidak melakukan Ta'shil Maraji' merujuk kepada buku aslinya langsung, sehingga banyak didapati kesalahan dalam pengutipan, contohnya kata "Kaffan" diartikan dengan tangan seharusnya telapak tangan. Dan dalam pernyataan Quraish Shihab yang mengatakan bahwa wanita-wanita yang tidak memakai jilbab belum dapat dinilai bahwa mereka telah melanggar tuntutan Allah. Alasan yang diungkapkan oleh Quraish Shihab tersebut sangat tidak ilmiah, yaitu dengan mengatakan bahwa jika sahabat Nabi hidup pada zaman sekarang boleh jadi pemahamannya berbeda. Maksudnya, mereka para sahabat jika hidup pada zaman sekarang, akan berpendapat juga bahwa jilbab itu tidak wajib. Dan ayat tentang jilbab yang terdapat dalam surat an-Nur ayat 31 dan surat al-Ahzab ayat 59, itu sudah merupakan kewajiban karena Asbab an Nuzul ayat tersebut sudah menunjukkan adanya sebab akibat adanya perintah tersebut.

\section{Pustaka Acuan}

Alquran dan Terjemahnya.

Al Ghifari, Kudung Gaul: Berjilbab Tapi Telanjang, Bandung: Mujahid Pers, 2003.

Abdul Mannan At-Taibiy, Ukasyah, Fatwa-fatwa Syaikh Albaniy, terj. Amiruddin Abdul Djalil, Jakarta: Pustaka Azzam, 2003. 
Abdillah Muhammad, Abi, bin Ahmad al Anshari al Qurtubi, Al Jami' Li Ahkamil Qur'an, Beirut: Darul Fikr, 1995.

Ali Al-Fadhl, Abu, bin Hasan bin Fadhl Ath-Thabrasi Majma' Al-Bayan fi Tafsir Alquran, Beirut: Darul Kutub Al-Ilmiyah, 1997.

Ála Al Maududi , Abul, Hijab, Beirut: Dar al Fikr, tt.

Al-Alusi, Mahmud, Ruh al-Ma'ani, Kairo: Al-Muniriyah, 1985.

Abu Bakar, Umar, Syaikh Muhammad Nasiruddin Al-Albaniy dalam Kenangan, terj. Abu Ihsan al-Asariy, Solo: Al-Tibyan, 1998.

Al Bukhari, Sahih al-Bukhari, Beirut: Dar al-Fikr, tt.

Ali, H. A. Mukti, Alam Pikiran Islam Modern di India dan Pakistan, Bandung: Mizan, 1993.

Asy Syaukani, Muhammad bin Ali bin Muhammad, Nailul Authar min Sayyid al Akhyar Syarhu Muntaha Mungal al Akhbar, Beirut: Dar al Kitab al Ilmiyah, 1995.

Ath-Thabari, Muhammad bin Jarir, Jami'ul Bayan fi Tafsiril Qur'an, Mekkah: Muassasah Ar- Risalah, 2000.

Ar Rifa'i, Muhammad Nasib, Ringkasan Tafsir Ibnu Katsir, Jakarta: Gema Insani, 2000.

Al-Biqa'i, Ibrahim bin Umar, Nazhm ad-Durar fi Tanasub al-Ayat wa as- Suwar, Beirut: Dar al-Kutub al-Ilmiyah, 1995.

Al-Ghazali, Muhammad, As-Sunnah An-Nabawiyah: Baina Ahl Al-Figh wa Ahl Al-Hadits, Kairo: Dar Asy-syuruq, 1989.

Bahrul Ulum, "Mukhlis Hanafi Bintang Muda Tafsir Alquran", Suara Hidayatullah, XX, 1 Mei, 2007.

Hasan, M. Ali, \& Syauqi Nawawi, Rif'at, Pengantar Ilmu Tafsir, Jakarta: PT. Bulan Bintang, 1988.

Husaini, Adian, "Jilbab": M. Quraish Shihab, Suara Hidayatullah XXIV, 7 November 2006.

Ibnu Katsir, Tafsir Alquran Al-Adzim, Cairo: Darul Hadits, 2003.

Nashiruddin, Muhammad al Albani, Jilbab Wanita Muslimah, Jogjakarta: Media Hidayah, 2002. 
Quraish Shihab, Muhammad, Tafsir al Misbah, Pesan, Kesan dan Keserasian al Qur'an, Jakarta: Lentera Hati, 2002.

Jilbab Pakaian Wanita Muslimah: Pandangan Ulama Masa Lalu dan Cendikiawan Kontemporer, Jakarta: Lentera Hati, 2006.

Wawasan Al-Quran: Tafsir Mawdhu'i atas Berbagai Persoalan Umat, Bandung: Mizan, 1998.

Surtiretna, Nina, Anggun Berjilbab, cet. II, Bandung: Al Bayan, 1996.

Syurbasyi, Ahmad, Study Tentang Sejarah Perkembangan Tafsir Alquran AlKarim, Jakarta: Kalam Mulia, 1999.

Zain An Najah, Ahmad, Jilbab Menurut Syariat Islam (Meluruskan Pandangan Quraish Shihab), Jakarta: Cakrawala Publishing, 2010. 